\title{
Tetrasomic inheritance and isozyme variation in Turnera ulmifolia vars. elegans Urb. and intermedia Urb. (Turneraceae)
}

\author{
JOEL S. SHORE \\ Department of Biology, York University, 4700 Keele St, North York, Ontario, Canada, M3J 1P3
}

\begin{abstract}
Tetrasomic inheritance of three isozyme loci is demonstrated in Turnera ulmifolia vars. elegans and intermedia. The data support the occurrence of an autopolyploid origin for tetraploids of both taxonomic varieties. The extent of isozyme variation at 14 loci was determined for diploid and tetraploid populations. Tetraploid Turnera ulmifolia var. intermedia showed the lowest levels of isozyme variation, perhaps a result of founder effect, upon island colonization. In contrast, Turnera ulmifolia var. elegans showed the greatest levels of isozyme variation, suggesting that hybridization among locally differentiated diploid or tetraploid populations might have occurred. The number of independent origins of autotetraploidy in Turnera ulmifolia is unknown.
\end{abstract}

Keywords: isozyme variation, tetrasomic inheritance.

\section{Introduction}

Turnera ulmifolia is a species complex of perennial weeds native to the Neotropics. The complex contains diploid, tetraploid, hexaploid and octoploid cytotypes and has a base number of $x=5$ (Raman \& Kesavan, 1964; Barrett, 1978; Arbo \& Fernandez, 1983; Shore \& Barrett, 1985a; Barrett \& Shore, 1987; Fernandez, 1987; Fernandez \& Arbo, 1989). Diploid and tetraploid populations are distylous and individuals are strongly self-incompatible and obligately outcross, while hexaploids of three taxonomic varieties are homostylous and self-compatible (Barrett, 1978; Shore \& Barrett, 1985b; Barrett \& Shore, 1987).

Turnera ulmifolia vars. elegans and intermedia are highly interfertile members of the species complex (Shore \& Barrett, 1985a; Arbo \& Fernandez, 1987; Shore, 1991) and diploid hybrids show regular bivalent formation at meiosis (Fernandez \& Arbo, 1989). The varieties are most easily distinguished by the presence of a purple petal spot in the cream-coloured corollas of T. ulmifolia var. elegans while var. intermedia has yellow flowers that lack the petal spot. Diploid populations of T. ulmifolia var. intermedia occur throughout Central America and in portions of South America, while tetraploid populations are apparently restricted to Puerto Rico and Hispaniola (Barrett \& Shore, 1987). Native populations of diploid and tetraploid $T$. ulmifolia var. elegans occur in Brazil. A tetraploid population that shares characteristics of both varieties occurs in Columbia (Barrett, 1978; Shore \& Barrett, 1985a), but insufficient numbers of plants were available for study.

Three lines of evidence suggest that tetraploid populations of T. ulmifolia vars. elegans and intermedia are autopolyploids. Cytological observations of tetraploids of both varieties have revealed the occurrence of quadrivalents at diakinesis and the first metaphase of meiosis, as well as reduced pollen fertility (Raman \& Kesavan, 1964; Arbo \& Fernandez, 1983; Fernandez, 1987; Shore, 1991). Finally, frequencies of meiotic configurations fit the autotetraploid pairing models of Jackson \& Hauber (1982) for four of six populations investigated (Shore, 1991).

In this paper, the hypothesis that T. ulmifolia vars. elegans and intermedia have had autotetraploid origins is tested and the genetic consequences of autotetraploidy is investigated. Genetic evidence is provided for autopolyploidy in these taxonomic varieties by demonstrating tetrasomic inheritance at three isozyme loci. To investigate the genetic consequences of autotetraploidy, levels of isozyme variation in diploid and tetraploid populations of $T$. ulmifolia were compared. Finally, the evidence bearing on the evolutionary origin of the tetraploid varieties was examined. 


\section{Materials and methods}

Bulk seed samples were collected from populations found throughout much of the native range of $T$. ulmifolia vars. intermedia and elegans. Seeds were germinated and population samples maintained in a glasshouse following the methods of Shore \& Barrett (1985a). The varietal status, sample size and ploidal level of populations sampled is provided in Table 1 .

Seven populations of tetraploid T. ulmifolia var. elegans were sampled from Brazil. For T. ulmifolia var. intermedia, seven diploid populations were sampled from Central and South America and 16 tetraploid populations were sampled from Puerto Rico and the

Table 1 Varietal status, population code, locality, ploidal level and sample size $(n)$ of Turnera ulmifolia populations used

\begin{tabular}{|c|c|c|c|}
\hline Population & Locality & $\begin{array}{l}\text { Ploidal } \\
\text { level }\end{array}$ & $n$ \\
\hline I1 & Barreirinhas, Brazil & $2 x$ & 18 \\
\hline $\mathrm{I} 2$ & Calabozo, Venezuela & $2 x$ & 12 \\
\hline I26 & Santa Rosa, Costa Rica & $2 x$ & 28 \\
\hline $\mathrm{I} 28$ & Santa Rosa, Costa Rica & $2 x$ & 8 \\
\hline I 29 & La Pacifica, Costa Rica & $2 x$ & 26 \\
\hline I31 & Juremal, Brazil & $2 x$ & 40 \\
\hline I35 & El Salvador & $2 x$ & 35 \\
\hline I8 & Rio Piedras, P.R. & $4 x$ & 14 \\
\hline I10 & Parbueyon, P.R. & $4 x$ & 40 \\
\hline I11 & Joyuna, P.R. & $4 x$ & 26 \\
\hline $\mathrm{I} 12$ & Dorado, P.R. & $4 x$ & 13 \\
\hline I13 & Manati, P.R. & $4 x$ & 11 \\
\hline $\mathrm{I} 14$ & Hwy 2 at 863 , P.R. & $4 x$ & 28 \\
\hline I15 & Hwy 2 at 671 , P.R. & $4 x$ & 6 \\
\hline I16 & Tortuguera, P.R. & $4 x$ & 20 \\
\hline I17 & Jarabacoa, D.R. & $4 x$ & 15 \\
\hline I18 & Santo Domingo, D.R. 1 & $4 x$ & 29 \\
\hline I19 & Cabrete, D.R. & $4 x$ & 10 \\
\hline $\mathrm{I} 20$ & San FCO de Macoris, D.R. & $4 x$ & 28 \\
\hline $\mathrm{I} 22$ & Lucas Diaz, D.R. & $4 x$ & 25 \\
\hline $\mathrm{I} 23$ & Bani at Playa, D.R. & $4 x$ & 12 \\
\hline I24 & St Cristobal, D.R. & $4 x$ & 21 \\
\hline 125 & Santo Domingo, D.R. 2 & $4 x$ & 27 \\
\hline E2 & Manaus, Brazil 1 & $4 x$ & 23 \\
\hline E3 & Belém, Brazil & $4 x$ & 25 \\
\hline E6 & Manaus, Brazil 1 & $4 x$ & 21 \\
\hline E7 & Recife, Brazil & $4 x$ & 21 \\
\hline E8 & Aracaju, Brazil & $4 x$ & 28 \\
\hline E9 & Maceio, Brazil & $4 x$ & 24 \\
\hline E10 & Vitória de S. Antão, Brazil & $4 x$ & 18 \\
\hline
\end{tabular}

$\mathrm{I}=$ variety intermedia,

$\mathrm{E}=$ variety elegans,

P.R. $=$ Puerto Rico,

D.R. $=$ Dominican Republic, $x=5$.
Dominican Republic. Note that population I31 has recently been found to be intersterile with other diploid populations and may represent an undescribed species of Turnera (Arbo \& Fernandez, 1987; M. M. Arbo, personal communication). Nevertheless, it is included in the analyses for comparisons of amounts of genetic variation between diploids and tetraploids (below). Diploid population I1 is considered to be T. ulmifolia var. intermedia, although, it is polymorphic for the presence of a purple petal spot characteristic of $T$. ulmifolia var. elegans (Shore \& Barrett, 1987; Barrett, 1978).

Horizonal starch gel electrophoresis was used to obtain allozyme data for 10 enzyme systems. Aconitase $(A c o)$, esterase $(E s t)$, glutamate dehydrogenase $(G d h)$, glutamate oxaloacetate transaminase (Got), glucosephosphate isomerase $(\mathrm{Gpi}$ ), leucine aminopeptidase (Lap), 6-phosphogluconate dehydrogenase $(P g d)$ and phosphoglucomutase $(\mathrm{Pgm})$, were assayed following Shore \& Barrett (1987). Malate dehydrogenase (Mdh) and alcohol dehydroganse $(A d h)$ were assayed following Cardy et al. (1980). Flower buds were used for the electrophoretic assays as they provided high levels of enzyme activity. For each enzyme, the locus coding the most anodally migrating protein was designated as locus 1 , the next locus 2 , etc., except where information was available on the intra-cellular location of the isozyme coded by the locus (Shore \& Barrett, 1987). Isozymes localized in the plastids are denoted by the letter ' $p$ ' and cytosolic isozymes by ' $c$ '. Allozymes coded by different alleles were designated by lower case letters, with the allele coding for the most anodally migrating allozyme designated ' $a$ ', the next 'b', etc. For ease of presentation, some alleles were re-coded for studies of inheritance (see below).

The inheritance of three isozyme loci, $A d h-2$ for $T$. ulmifolia var. intermedia and Aco-2 and Gpi-c for var. elegans was determined for tetraploids using controlled crosses of parents of known electrophoretic phenotype and assaying the resulting progeny. For $A d h-2$ (a dimeric enzyme), a plant putatively of tetrasomic genotype ffss was crossed to four individuals homozygous (genotype ffff) at this locus. A reciprocal cross was done for one of the individuals thus providing a total of five families. A total of 96 progeny was scored for $A d h-2$ activity by assaying mature pollen in which the locus is expressed.

For T. ulmifolia var. elegans, a heterozygous plant that was putatively tetra-allelic at the $A c o-2$ locus was obtained. The genotype of the plant was $a b c d$, where each letter refers to one of the four alleles producing electrophoretically distinguishable monomeric allozymes at this locus. The plant was crossed reciprocally to an individual of homozygous genotype, $b b b b$, and 
85 progeny were scored. The inheritance of Gpi-c (the cytosolic isozyme locus of the dimeric enzyme, glucosephosphate isomerase) was also assessed in $T$. ulmifolia var. elegans. An individual with a putative triallelic genotype was crossed with an individual that was di-allelic as follows: fmms $\times m m m s$ where $f, m$, and $s$, are three alleles at this locus. A total of 83 progeny was scored.

For all three loci, goodness of fit and heterogeneity tests were done to both tetrasomic (expected for autotetraploids) and two-locus disomic (expected for allotetraploids) models of inheritance, using the $G$ statistic (Sokal \& Rohlf, 1981). Tetrasomic ratios were predicted assuming no double reduction occurred at these loci (Allard, 1960).

A total of 652 individuals from 30 populations, representing both taxonomic varieties and ploidal levels, were analysed electrophoretically to compare levels of genetic variation across ploidal levels and taxa. For the 10 enzyme systems assayed, 14 loci could be resolved sufficiently well for both diploids and tetraploids. These were: Aco-1, Aco-2, Adh-1, Est, Gdh, Got-1, Got-2, Gpi-c, Gpi-p, Lap-1, Lap-2, Mdh-1, Pgd$c$, and Pgm-c. The inheritance of nine of the 14 loci has been determined for diploid T. ulmifolia (Shore \& Barrett, 1987). For tetraploids, the banding patterns were interpreted as if they were the result of tetrasomic inheritance, given the evidence below. It was necessary to infer the dosage of alleles from the relative intensity of the bands to determine the genotype of each tetraploid plant at each locus (e.g. Figs 1 and 2).

The percentage of polymorphic loci, mean number of alleles per locus, mean number of alleles per polymorphic locus, Nei's (1973) index of gene diversity and the observed proportion of heterozygosity were estimated for each population. Mean levels of genetic variation for each variety at each ploidal level were compared statistically, using the Wilcoxon rank-sum test, setting the experimentwise error rate at 0.05 , for the three comparisons.

The partitioning of total gene diversity $\left(H_{\mathrm{T}}\right)$ among populations $\left(D_{\mathrm{ST}}\right)$ of each variety at each ploidal level, as well as within populations $\left(H_{\mathrm{S}}\right)$, was assessed using the diversity analysis of Nei (1973). Gene diversity among populations relative to total diversity was calculated as $G_{\mathrm{ST}}=D_{\mathrm{ST}} / H_{\mathrm{T}}$. In addition, genetic distances were calculated among all pairs of populations followed by a UPGMA cluster analysis (Nei, 1987).

\section{Results}

\section{Inheritance of isozymes}

To test the hypothesis that tetraploid T. ulmifolia var. elegans and intermedia are autopolyploids, the inheritance of three isozyme loci was investigated. For $A d h-2$ in T. ulmifolia var. intermedia, segregation ratios from the cross ffss $\times f f f$ are presented in Table 2 . The parental and three progeny genotypes are shown in Fig. 1. Note that heterozygous genotypes, fffs and ffss, are readily distinguished by differences in banding intensity. The results fit the expected tetrasomic ratios while deviating significantly from a two-locus disomic model of inheritance. Progeny ratios among replicate crosses were homogeneous (Table 2).

The inheritance of two isozyme loci was determined for tetraploid T. ulmifolia var. elegans. For Gpi-c, progeny of the cross fmms $\times m m m s$ were scored and a photograph showing parental and progeny genotypes

Table 2 Tetrasomic inheritance of $A d h-2$ in tetraploid Turnera ulmifolia var. intermedia. Putative genotypes crossed were ffss $\times$ ffff and reciprocal. Goodness of fit $G$ tests to tetrasomic and two-locus disomic models of inheritance are provided as is a $G$ statistic for heterogeneity among crosses

\begin{tabular}{|c|c|c|c|c|c|c|}
\hline & \multicolumn{3}{|c|}{ Genotype } & \multirow[b]{2}{*}{$G$} & \multirow[b]{2}{*}{ d.f. } & \multirow[b]{2}{*}{$P$} \\
\hline & $f f f f$ & $f f f s$ & ffss & & & \\
\hline Progeny observed & 20 & 60 & 16 & & & \\
\hline Expected tetrasomic & 16 & 64 & 16 & 1.18 & 2 & $>0.50$ \\
\hline \multirow[t]{2}{*}{ Expected disomic } & 24 & 48 & 24 & 6.51 & 2 & $<0.05$ \\
\hline & \multicolumn{6}{|c|}{$G_{\text {heterogeneity }}=8.39$, d.f. $=8, P>0.25$} \\
\hline
\end{tabular}

d.f. $=$ degrees of freedom.
Fig. 1 Photograph of an isozyme gel for the $A d h$-2 locus. Parental (P1 and $\mathrm{P} 2$ ) and segregating progeny genotypes (lanes 1, 2 and 3) are indicated. Three different genotypes occur. The genotypes are: $\mathrm{P} 1$ and $1=f f s s ; \mathrm{P} 2$ and $2=f f f, 3=f f f$.

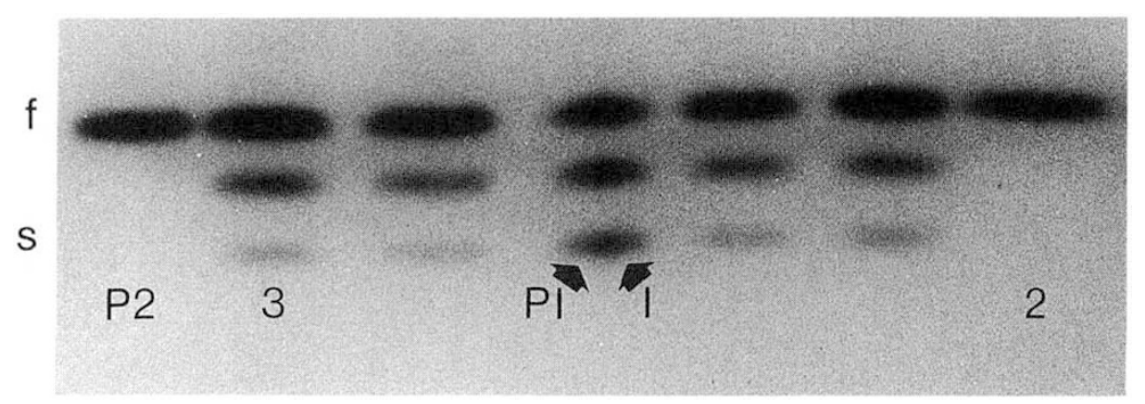


may be found in Barrett \& Shore (1989). Segregation ratios fit a tetrasomic model of inheritance and deviate significantly from a two-locus disomic model of inheritance (Table 3 ). The data also illustrate the occurrence of heterozygous plants containing three alleles at a single locus with some alleles carried in different doses.

For $A c o-2$, the cross $a b c d \times b b b b$ was made and progeny were scored and compared to expected tetrasomic ratios (Table 4). The parental plants and the six different progeny genotypes are shown in Fig. 2. No two-locus disomic model of inheritance can account for the production of six progeny genotypes, thus discounting this as a possible mechanism of inheritance. The progeny genotypes and segregation ratios are, however, consistent with a tetrasomic model of inheritance. There is no evidence of double reduction at this locus as additional progeny genotypes, that would uniquely mark the occurrence of double reduction, were not observed. The locus further illustrates the manner in which tetrasomic genotypes can be determined from electrophoretic phenotypes (Fig. 2).

\section{Isozyme variation in natural populations}

Levels of genetic variation within each population are presented in Table 5 and means for each variety at each ploidal level are provided in Table 6. Interestingly, there are differences in the levels of genetic variation for tetraploids of the two varieties (Tables 5 and 6). Tetraploid T. ulmifolia var. elegans exhibits significantly greater levels of genetic variation, as assessed by a Wilcoxon rank-sum test, for percentage polymorphic
Table 3 Tetrasomic inheritance of Gpi-c in var. elegans. The cross fmms $\times m m m s$ was carried out. Goodness of fit $G$ tests for tetrasomic and two-locus disomic models of inheritance are provided

\begin{tabular}{|c|c|c|c|c|c|c|c|c|c|}
\hline & \multicolumn{6}{|c|}{ Genotype } & \multirow[b]{2}{*}{$G$} & \multirow[b]{2}{*}{ d.f. } & \multirow[b]{2}{*}{$P$} \\
\hline & $f m m m$ & fmms & fmss & $m m m m$ & $m m m s$ & $m m s s$ & & & \\
\hline Progeny observed & 11 & 18 & 6 & 5 & 20 & 23 & & & \\
\hline Expected tetrasomic & 13.8 & 20.8 & 6.9 & 6.9 & 20.8 & 13.8 & 6.8 & 5 & $>0.2$ \\
\hline Expected disomic & 10.4 & 20.8 & 10.4 & 10.4 & 20.8 & 10.4 & 17.4 & 5 & $<0.01$ \\
\hline
\end{tabular}

d.f. $=$ degrees of freedom.

Table 4 Tetrasomic inheritance of Aco-2 in tetraploid Turnera ulmifolia var. elegans. Putative genotypes crossed were $a b c d \times b b b b$ and reciprocal. No two-locus disomic model can account for the occurrence of six progeny genotypes from this cross. Goodness of fit to a tetrasomic model of inheritance and heterogeneity $G$ statistics are provided

\begin{tabular}{|c|c|c|c|c|c|c|c|c|c|}
\hline & \multicolumn{6}{|c|}{ Genotype } & \multirow[b]{2}{*}{$G$} & \multirow[b]{2}{*}{ d.f. } & \multirow[b]{2}{*}{$P$} \\
\hline & $b b c d$ & $b b b d$ & $b b b c$ & $a b b d$ & $a b b c$ & $a b b b$ & & & \\
\hline Progeny observed & 19 & 14 & 11 & 13 & 14 & 14 & & & \\
\hline Expected tetrasomic & $\begin{array}{l}14.17 \\
G_{\text {beteros }}\end{array}$ & $\begin{array}{l}14.17 \\
\text { gencity }\end{array}$ & $\begin{array}{l}14.17 \\
5.09, \mathrm{~d} . f\end{array}$ & $\begin{array}{l}14.17 \\
=5, P\end{array}$ & $\begin{array}{r}14.17 \\
>0.25\end{array}$ & 14.17 & 2.36 & 5 & $>0.75$ \\
\hline
\end{tabular}

d.f. $=$ degrees of freedom

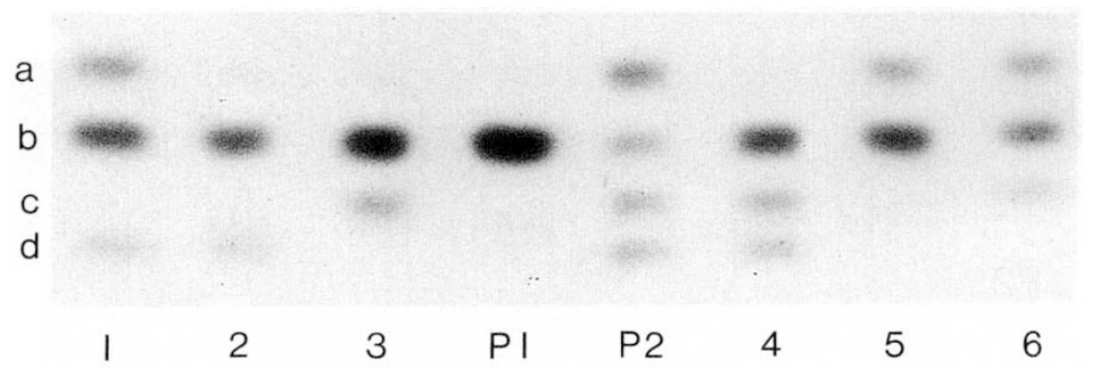

Fig. 2 Photograph of an isozyme ge! for the Aco-2 locus. Parental (lanes P1 and $\mathrm{P} 2$ ) and the six progeny genotypes observed (lanes 1-6) are shown. The genotypes are: $\mathrm{P} 1=b b b b ; \mathrm{P} 2=a b c d$; $1=a b b d ; 2=b b b d ; 3=b b b c ; 4=b b c d$; $5=a b b b ; 6=a b b c$. 
Table 5 Estimates of isozyme variation within populations of T. ulmifolia

\begin{tabular}{|c|c|c|c|c|c|c|}
\hline Population & $\begin{array}{l}\text { Ploidal } \\
\text { level }\end{array}$ & $\begin{array}{l}\text { Percentage } \\
\text { polymorphic } \\
\text { loci }\end{array}$ & $\begin{array}{l}\text { Mean } \\
\text { alleles/ } \\
\text { locus }\end{array}$ & $\begin{array}{l}\text { Mean } \\
\text { alleles/ } \\
\text { polymorphic } \\
\text { locus }\end{array}$ & $\begin{array}{l}\text { Gene } \\
\text { diversity }\end{array}$ & $\begin{array}{l}\text { Observed } \\
\text { heterozygosity }\end{array}$ \\
\hline I1 & $2 x$ & 50 & 1.5 & 2.0 & 0.16 & 0.17 \\
\hline 12 & $2 x$ & 43 & 1.6 & 2.3 & 0.09 & 0.08 \\
\hline 126 & $2 x$ & 43 & 1.5 & 2.2 & 0.11 & 0.09 \\
\hline 128 & $2 x$ & 50 & 1.6 & 2.1 & 0.15 & 0.10 \\
\hline 129 & $2 x$ & 36 & 1.4 & 2.2 & 0.08 & 0.07 \\
\hline 131 & $2 x$ & 43 & 1.6 & 2.5 & 0.11 & 0.08 \\
\hline 135 & $2 x$ & 57 & 1.6 & 2.1 & 0.19 & 0.17 \\
\hline 18 & $4 x$ & 21 & 1.2 & 2.0 & 0.03 & 0.06 \\
\hline $\mathrm{I10}$ & $4 x$ & 14 & 1.1 & 2.0 & 0.01 & 0.02 \\
\hline 111 & $4 x$ & 21 & 1.2 & 2.0 & 0.05 & 0.10 \\
\hline $\mathrm{I} 12$ & $4 x$ & 14 & 1.1 & 2.0 & 0.01 & 0.02 \\
\hline $\mathrm{I} 13$ & $4 x$ & 14 & 1.1 & 2.0 & 0.05 & 0.12 \\
\hline 114 & $4 x$ & 14 & 1.1 & 2.0 & 0.04 & 0.07 \\
\hline 115 & $4 x$ & 14 & 1.1 & 2.0 & 0.03 & 0.07 \\
\hline I16 & $4 x$ & 14 & 1.1 & 2.0 & 0.03 & 0.05 \\
\hline 117 & $4 x$ & 14 & 1.1 & 2.0 & 0.03 & 0.05 \\
\hline 118 & $4 x$ & 29 & 1.3 & 2.0 & 0.06 & 0.09 \\
\hline 119 & $4 x$ & 7 & 1.1 & 2.0 & 0.04 & 0.05 \\
\hline $\mathrm{I} 20$ & $4 x$ & 21 & 1.2 & 2.0 & 0.02 & 0.04 \\
\hline 122 & $4 x$ & 36 & 1.4 & 2.0 & 0.04 & 0.07 \\
\hline 123 & $4 x$ & 14 & 1.1 & 2.0 & 0.03 & 0.07 \\
\hline 124 & $4 x$ & 29 & 1.3 & 2.0 & 0.06 & 0.10 \\
\hline 125 & $4 x$ & 43 & 1.4 & 2.0 & 0.06 & 0.10 \\
\hline E2 & $4 x$ & 71 & 2.2 & 2.7 & 0.24 & 0.32 \\
\hline E3 & $4 x$ & 43 & 1.6 & 2.3 & 0.21 & 0.34 \\
\hline E6 & $4 x$ & 57 & 1.7 & 2.3 & 0.24 & 0.39 \\
\hline E7 & $4 x$ & 64 & 2.1 & 2.8 & 0.31 & 0.45 \\
\hline E8 & $4 x$ & 79 & 2.2 & 2.5 & 0.31 & 0.49 \\
\hline E9 & $4 x$ & 71 & 2.1 & 2.6 & 0.30 & 0.50 \\
\hline E10 & $4 x$ & 71 & 2.2 & 2.7 & 0.27 & 0.42 \\
\hline
\end{tabular}

Table 6 Mean levels of isozyme variation for each taxon/ploidal level. Means sharing the same letter $(\mathrm{a}, \mathrm{b}$ or $\mathrm{c})$ are not significantly different, based upon the Wilcoxon rank-sum test

\begin{tabular}{|c|c|c|c|c|c|c|}
\hline Taxon & $\begin{array}{l}\text { Ploidal } \\
\text { level }\end{array}$ & $\begin{array}{l}\text { Percentage } \\
\text { polymorphic } \\
\text { loci }\end{array}$ & $\begin{array}{l}\text { Mean } \\
\text { alleles/ } \\
\text { locus }\end{array}$ & $\begin{array}{l}\text { Mean } \\
\text { alleles/ } \\
\text { polymorphic } \\
\text { locus }\end{array}$ & $\begin{array}{l}\text { Gene } \\
\text { diversity }\end{array}$ & $\begin{array}{l}\text { Observed } \\
\text { heterozygosity }\end{array}$ \\
\hline Intermedia & $2 x$ & $45.9^{\mathrm{a}}$ & $1.55^{\mathrm{a}}$ & $2.20^{\mathrm{a}}$ & $0.12^{\mathrm{a}}$ & $0.11^{\mathrm{a}}$ \\
\hline Intermedia & $4 x$ & $20.1^{b}$ & $1.20^{\mathrm{b}}$ & $2.00^{b}$ & $0.04^{\mathrm{b}}$ & $0.07^{\mathrm{a}}$ \\
\hline Elegans & $4 x$ & $65.3^{c}$ & $2.03^{c}$ & $2.56^{c}$ & $0.27^{c}$ & $0.42^{b}$ \\
\hline
\end{tabular}

loci, mean number of alleles per locus and gene diversity, as well as having the greatest levels of observed heterozygosity. In marked contrast, tetraploid populations of T. ulmifolia var. intermedia exhibited the lowest estimates (Table 6). The means for diploids were intermediate.

Gene diversity was partitioned within and among populations of each variety at each ploidal level. Tetra- 
Table 7 Gene diversity statistics for T. ulmifolia vars. elegans and intermedia at each ploidal level

\begin{tabular}{llllll}
\hline Taxon & $\begin{array}{l}\text { Ploidal } \\
\text { level }\end{array}$ & $H_{\mathrm{S}}$ & $D_{\mathrm{ST}}$ & $H_{\mathrm{T}}$ & $G_{\mathrm{ST}}$ \\
\hline Intermedia & $2 x$ & 0.12 & 0.19 & 0.31 & 0.60 \\
Intermedia & $4 x$ & 0.04 & 0.01 & 0.05 & 0.21 \\
Elegans & $4 x$ & 0.27 & 0.07 & 0.34 & 0.21 \\
\hline
\end{tabular}

ploid T. ulmifolia var. intermedia exhibited low levels of total diversity $\left(H_{\mathrm{T}}=0.05\right)$, a greater proportion of which occurred within populations (Table 7). $T$. ulmifolia var. elegans exhibited the largest total gene diversity $\left(H_{\mathrm{T}}=0.34\right)$, again with the greater proportion occurring within populations $\left(H_{\mathrm{S}}=0.27\right)$. Diploid $T$. ulmifolia var. intermedia had a total gene diversity similar to that of var. elegans, however, 60 per cent of the diversity $\left(G_{\mathrm{ST}}=0.6\right)$ was partitioned between populations as compared to var. elegans, for which 21 per cent of the gene diversity $\left(G_{\mathrm{ST}}=0.21\right)$ occurred among populations.

Gene diversity for diploid T. ulmifolia var. intermedia populations was also calculated, excluding population I31, the potentially new species of Turnera. When this was done, the following diversity values were obtained: $H_{\mathrm{S}}=0.13, \quad D_{\mathrm{ST}}=0.12, \quad H_{\mathrm{T}}=0.24$, $G_{\mathrm{ST}}=0.48$. This analysis had the effect of reducing the total diversity as well as the between population component of diversity. Diploid T. ulmifolia var. intermedia, however, still had the largest proportion of gene diversity among populations, in comparison with the tetraploids.

To provide information on the possible origins of the polyploids, genetic distances among all populations were calculated and a UPGMA cluster analysis was used to construct a dendrogram (Fig. 3). In addition, the numbers of unique alleles present in each variety at each ploidal level were enumerated. Diploid $T$. ulmifolia var. intermedia (excluding population I31) had three unique alleles; tetraploid var. intermedia, one; and tetraploid var. elegans, six. The numbers of alleles present in the tetraploids that were not present in the diploids were also counted. For tetraploid $T$. ulmifolia var. intermedia, two alleles occurred that did not occur in the diploid populations. For tetraploid $T$. ulmifolia var. elegans, nine alleles occurred which were not represented in the diploids.

Diploid population I31 from Brazil proved to be genetically distant to the remaining populations (Fig. 3) supporting the crossing data of Arbo \& Fernandez (1987), which suggests that it should be recognized as a new species of Turnera. All 16 tetraploid populations

\section{Genetic distance}

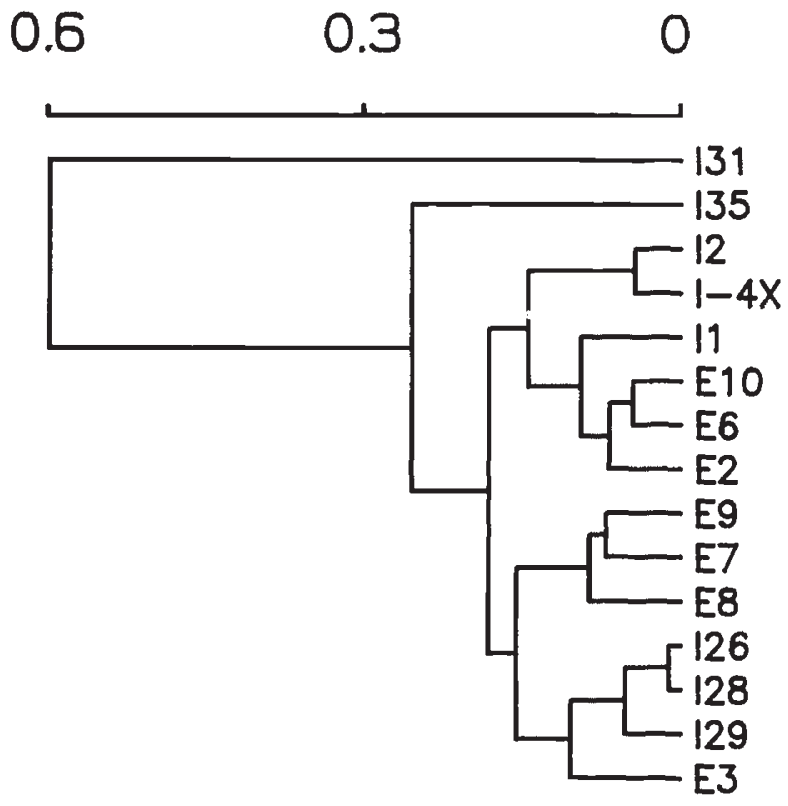

Fig. 3 Dendrogram produced from UPGMA clustering of genetic distances among populations of Turnera ulmifolia. I-4X represents a single cluster composed of all tetraploid var. intermedia populations.

of T. ulmifolia var. intermedia clustered together and are represented as $\mathrm{I}-4 \mathrm{X}$ (Fig. 3). Interestingly, these tetraploids clustered most closely with a diploid population of $T$. ulmifolia var. intermedia from Venezuela. The three Costa Rican diploids (populations I26, I28 and I29) form a cluster which also contains a Brazilian population (E7) of tetraploid $T$. ulmifolia var. elegans. Diploid population I1 clusters with some tetraploid T. ulmifolia var. elegans populations (populations E2, E6 and E10).

\section{Discussion}

The demonstration of tetrasomic inheritance at isozyme loci provides an independent source of evidence for autopolyploidy in tetraploid T. ulmifolia vars. elegans and intermedia. Coupled with cytological observations of chromosome configurations at meiosis (Raman \& Kesavan, 1964; Arbo \& Fernandez, 1983; Fernandez, 1987; Shore, 1991), and studies of the inheritance of distyly in tetraploids (Shore \& Barrett, 1985b), it provides strong support for autotetraploidy within this species complex. Thus, these taxonomic varieties of $T$. ulmifolia may be added to the relatively short list of natural autotetraploid plants (reviewed in Soltis \& Rieseberg, 1986; Krebs \& Hancock, 1989). 
Empirical studies of the genetic consequences of autopolyploidy are few in number (Soltis \& Rieseberg, 1986), however, the theoretical consequences have been examined. The population genetics of polysomy was formulated by Haldane (1930) and extended by other workers (e.g. Bennett, 1968; Wright, 1969; Mayo, 1971; McConnell \& Fyfe, 1975; Mayo, 1983). Autopolyploid populations should maintain greater levels of heterozygosity and exhibit greater resistance to allele frequency shifts due to drift than an otherwise comparable diploid population.

The manner in which an autopolyploid population becomes established may also have an important influence on the extent of genetic variation within the population. In particular, the amount of genetic variation that traverses the bottleneck between diploid and autopolyploid needs to be considered both theoretically and investigated experimentally. Furthermore, the history of the autopolyploid population and time since its origin need to be taken into account. For example, gene exchange with diploid populations via unreduced gametes (DeWett, 1979), or hybridization with autopolyploid populations of independent origin, might result in an influx of genetic variation.

Diploid and tetraploid T. ulmifolia var. elegans are sympatric in parts of their range (Shore \& Barrett, 1986; Barrett \& Shore, 1987), providing opportunities for gene exchange. No such opportunity, however, occurs for island populations of tetraploid T. ulmifolia var. intermedia. This may account for the striking difference in isozyme variation in the two autotetraploids. An additional possibility is that the occurrence of tetraploid T. ulmifolia var. intermedia on islands, and the resulting founder effect following long-distance dispersal could account for the low levels of isozyme variation. Island populations of Eichhornia paniculata (Glover \& Barrett, 1987) and Lycopersicon cheesmanii (Rick \& Fobes, 1975) have been found to be genetically depauperate in comparison with mainland populations.

Not only did tetraploid T. ulmifolia var. elegans have the greatest levels of genetic variation but, in addition, possessed nine alleles not found in the sample of diploid populations (six alleles were unique to tetraploid T. ulmifolia var, elegans). This could indicate that T. ulmifolia var. elegans has undergone hybridization with locally differentiated diploid populations that were not included in this study. Alternatively, a reduction in the effects of drift due to autopolyploidy and the accumulation of novel alleles via mutation, might account for these observations. Additional population samples, particularly of diploid $T$. ulmifolia var. elegans, are required to evaluate these alternatives.

Since tetraploid populations of T. ulmifolia are distylous and self-incompatible (Shore \& Barrett, 1985b; Barrett \& Shore, 1987), it is highly improbable that a single tetraploid plant could establish an obligately outcrossing, distylous, autotetraploid population. The number and source of individuals giving rise to autotetraploid populations and varieties is, however, unknown. The dendrogram (Fig. 3) indicates that tetraploid T. ulmifolia var. intermedia populations are most similar to a diploid var. intermedia population from Venezuela which, however, was represented by a small sample of plants. Different populations of tetraploid $T$. ulmifolia var. elegans clustered with different diploid var. intermedia populations, perhaps suggesting multiple origins of this variety. Information on the number of independent origins of autotetraploidy in $T$. ulmifolia will likely require the use of molecular biological methods, following the approach used by Soltis et al. (1989) for autopolyploid Heuchera micrantha.

\section{Acknowledgements}

I would like to thank Helen Rodd and Phillip Schappert for technical assistance, Spencer Barrett and Lorne Wolfe for seed samples and Helen Rodd for comments on the manuscript. This study was funded by Natural Sciences and Engineering Research Council operating grants to S. C. H. Barrett and J. S. Shore. Finally, I wish to thank Spencer Barrett for advice.

\section{References}

Allard, R. w. 1960. Principles of Plant Breeding. John Wiley and Sons, Toronto.

ARBo, M. M. AND FERnANDEZ, A. 1983. Posicion taxonomica, citologia y palinologia de tres niveles de ploidia de Turnera subulata Smith. Bonplandia, 5, 211-226.

ARBo, M. M. AND FERNANDEZ, A. 1987. Cruzamientos intra e interespecificos en Turnera, serie Canaligerae. Bonplandia, 6, 23-28.

BARRETT, S. C. H. 1978. Heterostyly in a tropical weed: the reproductive biology of the Turnera ulmifolia complex (Turneraceae). Can.J. Bot., 56, 1713-1725.

BARRETT, S. C. H. AND SHORE, J. S. 1987. Variation and evolution of breeding systems in the Turnera ulmifolia complex (Turneraceae). Evolution, 41, 340-354.

BARRETT, S. C. H. AND SHORE, J. S. 1989. Isozyme variation in colonizing plants. In: Soltis, D. E. and Soltis, P. S. (eds) Isozymes in Plant Biology. Dioscorides Press, Portland Oregon, pp. 106-126.

BENNETT, J. H. 1968. Mixed self- and cross-fertilization in a tetrasomic species. Biometrics, 24, 485-500.

CARDY, B. J., STUBER, C. W. AND GOODMAN, M. M. 1980. Techniques for starch gel electrophoresis of enzymes from maize (Zea mays L.). Institute of Statistics mimeo. Series no. 1317, North Carolina State University, Raieigh, NC.

DEWETT, J. M. J. 1979. Origins of polyploidy. In: Polyploidy: 
Biological Relevance, Lewis, W. H. (ed.), Plenum, New York, pp. 3-15.

FERnANDEZ, A. 1987. Estudios cromosomicos en Turnera y Piriqueta (Turneraceae). Bonplandia, 6, 1-21.

FERNANDEZ, A. AND ARBO, M. M. 1989. Relaciones genomicas entre cuatro especies diploides de Turnera con flores amarillas (Serie Canaligerae). Bonplandia, 6, 93-109.

GLOVER, D. E. AND BARRETT, S. C. H.. 1987. Genetic variation in continental and island populations of Eichhornia paniculata (Pontederiaceae). Heredity, 59, 7-17.

HALDANE, J. B. S. 1930. Theoretical genetics of autopolyploids. J. Genet., 22, 359-372.

JACKSON, R. C. AND HAUBER, D. P. 1982. Autotriploid and autotetraploid cytogenetic analyses: Correction coefficients for proposed binomial models. Am. J. Bot., 69, 644-646.

KREBS, S. L. AND HANCOCK, J. F. 1989. Tetrasomic inheritance of isoenzyme markers in the highbush blueberry, Vaccinium corymbosum L. Heredity, 63, 11-18.

MCCONNELL, G. AND FYFE, J. L. 1975. Mixed selfing and random mating with polysomic inheritance. Heredity, 34, $271-272$.

MAYO, O. 1971. Rates of change in gene frequency in tetrasomic organisms. Genetica, 42, 329-337.

MAYO, O. 1983. Natural Selection and its Constraints. Academic Press, Toronto.

NEI, M. 1973. Analysis of gene diversity in subdivided populations. Proc. Nat. Acad. Sci. USA, 70, 3321-3323.

NEI, M. 1987. Molecular Evolutionary Genetics, Columbia University Press, New York.

RAMAN, v. S. AND KESAVAN, P. C. 1964. Meiosis and the nature of polyploidy in Turnera ulmifolia. J. Indian Bot., 43, 495-497.
RiCK, C. M. AND FOBES, J. F. 1975. Allozymes of Galapagos tomatoes: Polymorphism, geographic distribution and affinities. Evolution, 29, 443-457.

SHORE, J. S. 1991. Chromosomal evidence for autotetraploidy in the Turnera ulmifolia L. complex (Turneraceae). Can.J. Bot. (in press).

SHORE, J. S. AND BARRETT, S. C. H. 1985a. Morphological differentiation and crossability among populations of the Turnera ulmifolia L. complex (Turneraceae). Syst. Bot., 10, 308-321.

SHORE, J. S. AND BARRETT, S. C. H. 1985 b. Genetics of distyly and homostyly in the Turnera ulmifolia complex (Turneraceae). Heredity, 55, 167-174.

SHORE, J. S. AND BARRETT, S. C. H. 1986. Genetic modifications of dimorphic incompatibility in the Turnera ulmifolia complex (Turneraceae). Can. J. Genet. Cytol., 28, 796-807.

SHORE, J. S. AND BARRETT, S. C. H. 1987. Inheritance of floral and isozyme polymorphisms in Turnera ulmifolia L. J. Hered., 78, 44-48.

SOKAL, R. R. AND ROHLF, F. J. 1981. Biometry. Freeman, San Francisco.

SOLTIS, D. E. AND RIESEBERG, L. H. 1986. Autopolyploidy in Tolmiea menziesii (Saxifragaceae): Genetic insights from enzyme electrophoresis. Am. J. Bot., 73, 310-318.

SOLTIS, D. E., SOLTIS, P. S. AND NESS, B. D. 1989. Chloroplast-DNA variation and multiple origins of autopolyploidy in Heuchera micrantha (Saxifragaceae). Evolution, 43, 650-656.

WRIGHT, s. 1969. Evolution and Genetics of Populations, Vol. 2, The Theory of Gene Frequencies, University of Chicago Press, Chicago. 